\title{
THE POLICY DEBATE ON PATIENT CARE FINANCING FOR VICTIMS OF END-STAGE RENAL DISEASE*
}

\author{
RICHARD A. RETTIG ${ }^{\dagger}$
}

\section{INTRODUCTION}

It was Saturday morning, September 30, 1972, barely one month before the November presidential election. The Senate was in session, hardly a normal weekend event in Washington. It was rushing to complete action on H.R. 1, the Social Security Amendments of 1972. At 11:30 a.m., Senator Vance Hartke of Indiana secured the floor and proposed that the bill be amended to extend Medicare coverage to victims of end-stage renal disease. ${ }^{1}$ This coverage would preserve the lives of relatively few individuals, at a very substantial cost. During the brief debate-thirty minutes were allocated to the amendment-only Senator Wallace Bennett of Utah spoke against the provision. With nearly half the Senate members absent, the measure was adopted by a vote of fifty-two "Yeas" and three "Nays."

The remaining steps of the legislative process were traversed with comparable speed. The conference committee of the House Ways and Means Committee and the Senate Finance Committee met for only a single day to consider differences on the entire bill. The kidney disease amendment received no more than ten minutes' discussion and the Senate proposal was accepted in its essentials with a slight modification in one provision. Both House and Senate accepted the conference committee report on October 17 , and President Nixon signed H.R. 1 into law as Public Law 92-603 on October 30, 1972.3 The kidney disease provision was included as section 299I. In this way, the nation resolved an extended policy debate over kidney disease that reached back more than a decade.

\footnotetext{
* The author is indebted to James W. Vaupel. Philip J. Cook, and Peter Buck of Duke University for their constructive comments on earlier drafts. Support for the research on which this paper is based was provided by the National Science Foundation (Grant No. G1-39327) while the author was at Ohio State University.

$\div$ The Rand Corporation, Washington, D.C

1. Chronic or end-stage renal disease is that clinical condition reached when an individual has experienced such a degree of irreversible deterioration of kidney function that, without treatment. death will soon follow. Renal means pertaining to the kidneys, from ren, the Latin word for kidney.

2. 118 CoNG, Rec. 33009 (1972).

3. See Social Security Amendments of 1972. 42 U.S.C. $\$ 426(e)(3)$ (1974).
} 
This paper is an analysis of that policy debate, one that deserves our attention for at least two reasons. First, it is thought by many that the kidney disease amendment is an instance of the unwillingness of public officials to withhold financial assistance to an identified set of individuals who would clearly die without such assistance. Zeckhauser, for example, has argued: ${ }^{4}$

\begin{abstract}
When risks of lives are involved, an important valued belief is that society will not give up a life to save dollars, even a great many dollars. Rarely is this belief, widely held albeit mistaken, put to a clear test. When it is, it may be desirable for society to spend an inordinate amount on each of a few lives to preserve a comforting myth. Such a myth-preserving action was taken when the federal government assumed the costs of renal dialysis.
\end{abstract}

The analysis of the policy debate preceding the enactment of Section 2991 provides evidence pertinent to evaluating this claim that society is unwilling to sacrifice lives for dollars. Though Zeckhauser's interpretation may be of some merit, it tends to exaggerate the importance of the "myth." It overlooks the length of the policy debate over federal responsibility for financing the treatment of individuals having end-stage renal disease, a debate that began in the early 1960 s and was not resolved until 1972, and it overlooks the strong resistance to patient care financing that was encountered at every juncture of the debate, even though the plight of victims of kidney failure continued to be dramatized by the news media. Finally, the "myth preserving" interpretation overlooks the alternative explanation that the 1972 legislation was the practically inevitable next step in a series of partial federal government responses to the existence of the life-saving therapies of hemodialysis and renal transplantation.

The second reason for analyzing the end-stage renal disease policy debate is to consider its implications for other diseases that might be candidates for catastrophic health insurance coverage. A panel of the Institute of Medicine, for instance, worried in 1973 that Section 2991 might become a precedent for extending such coverage to other clinical conditions on a categorical diseaseby-disease basis. ${ }^{5}$ Hemophilia victims, for example, would appear to have as valid a claim to federal patient treatment financing as kidney failure victims. The policy debate on kidney disease, however, strongly suggests that more than the existence of life-saving therapy and an identified group of patients is needed before government action is forthcoming.

4. Zeckhauser, Procedures for Valuing Lives, 23 Pub. Policy 419, 447 (1975). While I disagree with Zeckhauser's interpretations of the meaning of the end-stage renal disease decision, his emphasis on the importance of procedures is fully shared. The case of policy debate on end-stage renal disease, moreover, points out the importance of policy-making procedures as well as analytic procedures.

5. Natl academy of Sciences, Institute of Medicine, Report of the Panel on implications of a Categorical Catastrophic Approach to National Health lnsurance (1973). 


\section{BACKGROUND}

In the 1960s two therapies-hemodialysis and renal transplantationemerged which had the capability of saving the lives of individuals with chronic (or end-stage) kidney failure. Hemodialysis is the process by which metabolic waste products normally cleared by the kidney through the urinary tract are "washed" from the blood stream by means of an artificial kidney. Renal transplantation is that surgical procedure by which a healthy kidney from one individual is implanted in an individual with end-stage renal disease; the transplanted kidney functions as the individual's own kidneys once did. Clinically, the artificial kidney machine is the first artificial substitute for a whole organ and kidney transplantation is the first surgical procedure for transplanting a whole natural organ from one individual to another. These therapies are non-elective procedures for those with end-stage renal disease; if they do not receive this treatment they die.

In Public Law 92-603, the Social Security Amendments of 1972, Medicare health insurance coverage for end-stage renal disease was effectively extended to more than 90 per cent of the population of the United States. The 1965 law which established Medicare provided health insurance coverage to the aged-those over sixty-five years of age-and this included coverage for renal failure. ${ }^{6}$ Restrictive patient selection criteria for hemodialysis and renal transplantation patients, and limited knowledge of this specific form of the general benefit, however, resulted in receipt by relatively few individuals of Medicare benefits for end-stage renal disease.

Public Law 92-603, enacted on October 30, 1972, provided Medicare coverage to the under-65 population and did so in two ways. First, those individuals under age sixty-five who qualified for cash benefits under social security or the railroad retirement system because of a disability so incapacitating that they were prevented from working became eligible, after a twenty-four month waiting period, for Medicare's hospital and supplementary medical insurance protection. ${ }^{7}$ This protection included coverage for end-stage renal disease.

Second, a substantial number of potential end-stage renal disease patients, approximately sixty per cent of the total, could not qualify for Medicare on either the basis of age or entitlement to cash disability benefits. Medicare coverage was extended to this larger group by section $299 \mathrm{I}$ of the Act. Section 2991 provided that every individual not yet sixty-five years old, who

6. Subcomm. on Health and Subcomm. on Oversight of the House Comm. on Ways and Means, 94th Cong., lst Sess., Background Information on Kidney Disease Benefits Under Medicare 4 (Comm. Print 1975) [hereinafter cited as Ways and Means, Background InforMATION].

7. Ways and Means, Background Information 3. 
was fully or currently insured or entitled to monthly insurance benefits under social security, or who was the spouse or dependent child of such an individual, and who was "medically determined to have chronic renal disease" and to require hemodialysis or renal transplantation, shall, in the language of the Act, "be deemed to be disabled for purposes of coverage under parts A and B of Medicare subject to the deductible, premium, and co-payment provisions of Title XVIII." 8

Both renal dialysis and transplantation are very expensive therapies, requiring resources normally well beyond the financial means of all but the most affluent. A General Accounting Office (GAO) study of the costs of dialysis, based upon 1972 data for ninety-six center dialysis programs in eleven states and two counties, and ten home dialysis programs in six states, indicated the following:"

TABLE I

Annual Cost of Dialysis

\begin{tabular}{lccccc}
\hline & \multicolumn{4}{c}{ Center Dialysis (96) } & Home Dialysis (10) \\
\hline & $\begin{array}{c}\text { Total } \\
(96)\end{array}$ & $\begin{array}{c}\text { Hospital } \\
(81)\end{array}$ & $\begin{array}{c}\text { Non-Hospital } \\
(15)\end{array}$ & lst Year & 2nd Year \\
\hline Average & & & & & \\
Charge & $\$ 30,100$ & $\$ 30.500$ & $\$ 27.600$ & $\$ 14.900$ & $\$ 7.000$ \\
Range & & $11,500-$ & $12,800-$ & & \\
& & 49,100 & 46,800 & & \\
\hline
\end{tabular}

Source: Comptroller General of The U.S., Treatment of Chronic Kidney Failure: Dialysis, Transplant, Costs, and the Need for More Vigorous Efforts $40-41$ (1975).

Note: Data are for 1972 .

The costs of transplantation are also significant. Charges for 1973 in twentyfour facilities analyzed by the GAO ranged from $\$ 5,500$ to $\$ 20,500$ and averaged about $\$ 12,800$. The Department of Health, Education, and Welfare cited costs to the GAO of $\$ 14,000$ for a transplant from a living related donor. Included in costs were hospital room, board, ancillary charges, and professional fees. ${ }^{1 "}$ The costs of therapy to a given individual can vary substantially according to the therapy or combination of therapies received and a number of other contingencies. All methods of therapy are expensive, a successful transplant being by far the least costly and most satisfactory mode of therapy.

8. Social Security Amendments of 1972, § 2991, 42 U.S.C. $\$ 426(e)(3)$ (1974).

9. See Comptroller General of the U.S., Treatment of Chronic kidney Failure: Dialysis, Transplant, Costs, and the Need for More Vigorous Efforts 40-41 (1975).

10. Id. at $43-44$. 
Prior to passage of section 299I, the number of beneficiaries of end-stage renal disease treatment was relatively small. The number of reported dialysis patients alive in July 1970 was 2,874; in July 1971, it was 4,375; and a year later, 5,786. ${ }^{11}$ The total number of kidney transplants reported for 1967 , $1968,1969,1970$, and 1971 was $428,635,787,996$, and 1,172 respectively. ${ }^{12}$ Since passage of the Act, the number of beneficiaries has greatly increased, although the total number is still a small fraction of the population of the United States. The number of renal disease patients who had qualified for Medicare coverage as of March 31, 1975 was 25,066, of whom 20,764 were still living as of that date. ${ }^{13}$ Approximately 60 per cent of the total qualified on the basis of section 299I. It is estimated that the number of patients alive and receiving renal disease benefits will reach 50,000 to 70,000 by $1990 .{ }^{14}$ It is interesting to note, by contrast, the situation affecting hemophiliacs. Although legislation has been introduced in recent Congresses to extend financial assistance for treatment payment to hemophiliacs, Medicare coverage has not yet been made available. Hemophilia is a disease whose central symptom is serious bleeding. The estimated number of patients is 100,000 , of whom approximately 25,000 are severely or moderately severely affected. These 25,000 patients require continuous replacement of fresh whole blood, plasma, or clotting concentrates. Replacement materials cost from $\$ 2,000$ to $\$ 5,000$ per patient per year. Costs of replacement therapy, and of reconstructive surgery for the most severely crippled, are rarely covered by third-party payments. Therapy capable of preventing bleeding episodes is far more expensive and can range from $\$ 20,000$ to $\$ 40,000$ per year. ${ }^{15}$

The extended Medicare coverage for end-stage renal disease went into effect on July 1, 1973. The estimated incurred costs for the first year of the

11. See Research Triangle Institute, Natl Dialysis Registry: Second Annual Progress Report, July 1, 1969-June 30, 1970 (1970); Third Annual Progress Report, July 1, 1970-June 30, 1971 (1971); Fourth Annual Progress Report, July 1, 1971 -June 30, 1972 (1972). The national dialysis patient load reported in January 1971, January 1972, January 1973, and January 1974, respectively, was 16.6 cases per million population, 24.4 per million, 37.4 million, and 46.9 per million. See National institutes of Health, Proceedings of the 4th, 5Th, 6th, \& 7 th Annual Contractors' Conference of the Artificial Kidney Program of the Nat'l Institute of Arthritis and Metabolic Disease (1971, 1972, 1973, 1974).

12. See National Institutes of Health, U.S. Kidney Transplant Fact Book: Information From ACS/NIH REGISTRY 1972, at 10 (1972). There are several indications that data supplied to the American College of Surgeons/National Institutes of Health Organ Transplant Registry underreport the kidney transplants performed in the United States by nearly 50 per cent. For an analysis of this problem, see $\mathrm{J}$. Sullivan, The Role of Data in End-Stage Renal Disease Programs (1975) (unpublished thesis at Hospital and Health Services Administration, Ohio State University).

13. WAYS AND MEANS, BaCKgROUND INFORMATION 6.

14. Id. at 2 .

15. See Hearings on National Health Insurance Before the House Comm. on Ways and Means, 93d Cong., 2d Sess., pt. 8, at 2400 (1974) (testimony of Margaret W. Hilgartner, M.D. and Louis N. Friedland). 
program were $\$ 150$ million for section 2991 beneficiaries and an additional $\$ 100$ million for patients eligible under the aged and disabled provisions. The estimated incurred costs for the first, second, third, and fourth years for both section 2991 and all Medicare renal patients are shown below. It is estimated that the annual costs for renal disease patients will exceed $\$ 1$ billion by $1984 .^{16}$

TABLE II

Estimated Medicare Incurred Costs of End-Stage Renal Disease

(in millions)

\begin{tabular}{lrrrr}
\hline & \multicolumn{5}{c}{ Fiscal Year- } \\
& 1974 & 1975 & 1976 & 1977 \\
\hline Sec. 2991 patients & $\$ 150$ & $\$ 225$ & $\$ 300$ & $\$ 360$ \\
All renal patients & 250 & 350 & 500 & 600 \\
\hline
\end{tabular}

Source: Ways and Means, Background Information 15.

II

The Beginnings of the Policy Debate

In order to understand how society grappled with value-of-life decisions posed by section 299I, it is important to recognize that the nature of the end-stage renal disease issue was clearly understood at least a decade before the matter was resolved. The federal government did not move in haste or in ignorance to the decision it made in 1972.

The use of the artificial kidney machine for providing long-term, intermittent hemodialysis for preserving lives of individuals with end-stage renal disease became possible in 1960. In that year, Dr. Belding H. Scribner, a physician at the University of Washington School of Medicine, and his colleagues invented a vascular access device known as a "cannulae" and "shunt." This device made it possible to connect patients to an artificial kidney machine for the purpose of cleansing their bloodstream of the products of metabolic waste and then to disconnect them at the end of ten to twelve hours of treatment. ${ }^{17}$

16. Ways and Means, Background Information 15.

17. The announcement of the invention of the cannulae and shunt was made in three papers in the publication of the American Society for Artificial Internal Organs. Scribner, Caner, Buri, \& Quinton, The Technique of Continuous Hemodialysis, 6 Transactions Am. Soc'y Artificial. Internal Organs 88 (1960); Quinton, Dillard, \& Scribner, Cannulation of Blood Vessels for Prolonged Hemodialysis, 6 Transactions Am. Soc'y Artificial Internal Organs 104 (1960); Scribner, Buri, Caner, Hegstrom, \& Burnell, The Treatment of Chronic Uremia by Means of Intermittent Hemodialysis: A Preliminary Report, 6 Transactions Am. Soc'y Artificial Internal Organs $114(1960)$. 
Scribner inserted the cannulae and shunt in his first patient on March 9 , 1960, and immediately began dialysis. Scribner was so enthusiastic about his technique that he took ten "how to do it" kits to Chicago the next month, where he demonstrated for his medical-scientific colleagues the process of patient cannulation. ${ }^{18}$ Clyde Shields, his first patient, also made the trip. Scribner's own account of that meeting indicates that there was general agreement that the cannulation technique was promising but that considerable pessimism existed regarding the biochemical aspects of dialysis. Questions dealing with the potential patient load revealed substantial differences of opinion, but most thought the load would be considerable. Efforts to determine the size of that load were deferred to a later date. "The question of public release of information and fund raising was not discussed in detail," Scribner wrote, "because it is just too early to say much."19

On May 19, 1960, Scribner wrote Dr. George M. Wheatley, a vice president of Metropolitan Life Insurance Company in New York City, to inquire about prospective patient load data: "It is becoming more and more clear that by this technique of continuous hemodialysis and the technique of cannulation of the blood vessels, we are going to considerably alter the course of terminal illness in patients with chronic uremia." ${ }^{2}$ Clearly, moving this new medical technique from clinical research to widespread medical use was of great importance to Scribner within weeks of his first patients being placed upon the machine.

Costs also came quickly into focus. July 1960 estimates by Scribner of costs for treating fifteen patients came to $\$ 99,000-\$ 16,000$ for equipment, $\$ 40,000$ for once-a-week dialysis, and $\$ 43,000$ for medical personnel. ${ }^{21}$ Minus equipment, per patient costs were $\$ 5,533$ per year. The recognition that thrice-weekly dialysis was medically more desirable later exposed these estimates as quite low. Even so, it was clear from the start that substantial costs were associated with this new procedure.

By 1962, cost considerations and the related scarcity of facilities permeated all discussions of dialysis. Writing in the New York Times about the Seattle experience, Harold Schmeck called the emergence of hemodialysis "[o]ne of the most dramatic stories of medical triumph and tragedy in recent history." ${ }^{2}$

18. The demonstration of the invention actually occurred in Scribner's hotel room in a special session arranged by Dr. George E. Schreiner; approximately ten people were invited. This session was held during the annual meeting of the American Society for Artificial Internal Organs. The three papers cited in note 17 supra were not formally presented at the time, but were submitted afterward at Schreiner's request.

19. B. Scribner, Report on the Chicago Meeting (April 13, 1960) (unpublished memorandum on file with the author).

20. Letter from Belding H. Scribner to George Wheatley (May 19, 1960).

21. Memorandum from Belding $H$. Scribner to Walter S. Tuesly, Director, Seattle Foundation, Community Dialysis Center for King County (Preliminary Considerations) (July 5, 1960).

22. Schmeck, Panel Holds Life-or-Death Vote in Allotting of Artificial Kidney, N.Y. Times, May 6 , 1962, at 1. col. 5. 
The triumph lay in the fact that "[a] handful of men and women who should be dead, by normal medical criteria, are living and leading nearly normal lives." The tragedy lay in the fact that "because facilities for cure are limited, inevitable death of kidney disease [was in store] for thousands of others." Annual costs of treatment were estimated to be $\$ 10,000$ per patient.

In early November 1962, a Life magazine article by Shana Alexander described the dilemma created by the existence of a life-saving therapy and the scarcity of facilities to provide it. ${ }^{23}$ Treatment costs were estimated to be $\$ 15,000$ per patient per year. The article went on to describe the anonymous, seven-member lay committee in Seattle which was charged with deciding which individuals should have access to the limited number of machines after medical evaluation of prospective patients. Factors identified as important to the committee in their determinations included the patient's age and sex, marital status and number of dependents, income, net worth, emotional stability, educational background, occupation, past performance, future potential, and personal references. The value-of-life dilemma was thus conveyed in stark terms to an audience of millions.

At a joint conference in June 1963 between the American Medical Association and the National Kidney Disease Foundation, the Seattle presentation enumerated "adequate funding" and preparation as the first of several prerequisites for a successful hemodialysis treatment program. ${ }^{24}$ Costs, it was indicated, could reach "upwards of $\$ 20,000$ per patient per year," and initial capitalization for a ten-bed center was estimated to be $\$ 300,000$ to $\$ 500,000$. The financial workshop report indicated that it "has asked more questions than it has been able to find answers for at this point." The workshop on socioeconomic and moral questions, however, headed by a Jesuit priest, put the problem in clearer perspective: ${ }^{25}$
At this moment there are only a certain number of people who are able to be helped through the technique of hemodialysis. In the immediate future, also, just a small number of people will be able to be treated. No matter what the decision of our conferences about the medical and financial factors, the im- plementation of a full-scale program will take a number of years. Therefore, we in this country will be faced with the moral problem of having at hand a method of saving life which is not available to all who need it.

Finally, the implications of hemodialysis for the federal government were also recognized early. In 1964, the Senate Appropriations Committee indicated that the Public Health Service had the statutory authority to provide

23. Alexander, They Decide Who Lives, Who Dies, 53 Life, Nov. 9, 1962, at 102-04.

24. Suggestions Regarding Activation and Operation of Community Hemodialysis Centers for the Treatment of Chronic Uremia, in American Medical Ass'n \& Nat'l Kidney Disease Foundation, Proceedings, Conference to Consider the Treatment of Patients with Chronic Kidney Disease with Uremia 20-28 (1963) [hereinafter cited as Conference Proceedings].

25. Id. at 51 . 
demonstration and training funds for artificial kidney programs. That authority, however, did not extend to patient-care financing: ${ }^{26}$

The Federal Government has borne the cost of treatment for its legal beneficiaries and shared these treatment costs when it has been in connection with research investigation or demonstration. Traditionally, payment for treatment of illness has been the responsibility of the patient or the local community. If the Federal Government were to share the full cost of lifetime treatment for all who suffer from these chronic diseases and conditions, the financial burden would be excessive.

\section{III}

\section{Major Factors Affecting the Policy Debate}

Six factors played major roles in the lengthy policy debate on patient-care financing. These factors were:

1. The changing evaluation of the two life-saving medical procedures - dialysis and transplantation-as they were clinically developed;

2. the changing distribution of power within the medical-scientific community;

3. the gradual extension of government involvement in renal disease;

4. the evolution of the federal role in health care in general;

5. the importance of identifying and publicizing the lives at stake; and

6 . the "sotto voce" character of the policy debates.

Each of these elements deserves close analysis.

\section{A. Changing Treatment Evaluation}

The evaluation of a new medical procedure by the medical-scientific community depends upon a number of factors. Most important, at least in this case, were the location of the procedure on the "experiment-therapy continuum," the quality of life provided patients by the procedure, the therapeutic alternatives, and the aesthetic nature of the therapy.

\section{The Experiment-Therapy Continuum}

Fox and Swazey have suggested that it is appropriate to speak of an experiment-therapy continuum for any given medical procedure. ${ }^{27} \mathrm{~A}$ procedure may be clearly experimental or clearly an established therapy, but new procedures are frequently in some intermediate postion, moving from the experimental to the therapeutic. Clinical investigation, they note, involves the interplay between research and therapy, and the balance between the two "shifts as the new treatment evolves." ${ }^{2}$ The precise location of a new medical

26. S. Rep. No. 1460, 88th Cong., 2d Sess. 20 (1964).

27. R. Fox \& J. Swazey, The Courage to Fall: A Social View of Organ Transplants and DiAlysis 60-83 (1974).

28. Id. at 64 . 
procedure along this continuum, quite obviously, will have a large bearing upon the policy debate about how the federal government should react to the procedure. If it is experimental, then research is clearly indicated. If it is established therapy, however, other responses might and probably will be called for. But the position of a given procedure on this continuum at a particular time is difficult to establish.

Two sources of ambiguity complicate this assessment. First, Fox and Swazey point out, there are semantic difficulties: "Physicians do not have standardized and unevocative terms to designate the stages of development of a new therapy clearly and objectively." ${ }^{29}$ No a priori criteria exist by which the medical community can make such judgments. Second, the role of the clinical investigator is structurally ambivalent because of his orientation to the provision of therapy to sick patients and his concurrent commitment to "the advancement of scientific understanding" of clinical medicine. Clinical investigators differ markedly in their emotional involvement in both the investigative and therapeutic aspects of their dual role. The dilemma confronting the clinical investigator has been described in this way: "The research physician's attempt to equilibrate his clinical and investigative responsibilities is related to a basic problem: determining how experimental and/or therapeutic a new operation, drug, or other procedure is at a given time in its development and for a given class of sick persons." ${ }^{4 \prime)}$ Consequently, among clinical investigators the "scientist" is likely to emphasize the unknowns and uncertainties of a new procedure, to stress the limits of knowledge, and to regard it as experimental for a longer time than a "physician." By contrast, the "physician" is likely to emphasize the prospective benefits of a new procedure and de-emphasize the associated uncertainties.

The policy debate over end-stage renal disease was affected by differences of opinion within the medical-scientific community as to where the therapies of dialysis and transplantation were along the experiment-therapy continuum. For instance, when Scribner first introduced his cannulation technique in 1960, Dr. John P. Merrill, who had extensive experience with dialysis in connection with the transplantation program at Peter Bent Brigham Hospital in Boston, suggested that patient weight loss and mental deterioration were likely to occur on long-term dialysis. George E. Schreiner, a Georgetown University physician and one of the pioneers in the use of dialysis with acute renal failure, supported Merrill's views. ${ }^{31}$ Subsequently, many physicians who attempted to replicate Scribner's work were unable to do so. Charges were made that Scribner kept his patients alive only by heroic dedication and energy and not by clinical understanding of the dialysis experience.

29. Id.

30. Id. at 63 .

31. This is reported in B. Scribner, supra note 19. 
In June 1963, however, at the meeting sponsored by the American Medical Association and the National Kidney Disease Foundation, ${ }^{32}$ Merrill changed his position and announced that hemodialysis could be regarded as an established therapeutic procedure: ${ }^{33}$

My colleagues and I at Peter Bent Brigham and others have used Dr. Scribner's technique and while difficulties were encountered at first, we have found that it is now possible to use this method. It is important to emphasize this fact about hemodialysis because it is no longer in the experimental stage. It is now a practical method, as far as some physicians are concerned, by which to keep chronic uremia patients alive. I believe the problem of hemodialysis must be looked at in this light.

Schreiner, speaking at this same meeting, was far more conservative; "let me emphasize," he said, "that no matter what you have read or heard, there are problems connected with the use of these techniques, both in a research setting and on a community-wide basis." 34 Thus, the community was hardly of one mind on the status of hemodialysis. Since the conference considered the financial questions posed by dialysis, as well as its moral-ethical implications, differences of opinion within the medical-scientific community entered directly into the policy debate.

The development of kidney transplantation also raised the question of where that procedure was on the experiment-therapy continuum. The implications of the status of both dialysis and transplantation were addressed in an editorial in Modern Medicine. ${ }^{35}$ The editor, Irving H. Page, M.D., described chronic dialysis as "an interesting and important experiment." 36 He was exceptionally critical of recent initiatives within the Public Health Service and the Veterans Administration to establish dialysis centers around the country. He also stated categorically "that it should be perfectly clear that we are not ready for large-scale kidney transplantation" until the rejection problem had been overcome. Then, to his physician audience, he argued: "We have a responsibility to help guide other human beings through life and not to hold out hope of . . a normal life-span when this hope is not justified." 37

By late 1964 the debate was still not settled. In an article primarily describing the Seattle experience with home dialysis, Medical World News quoted Dr. Norman G. Levinsky, director of Boston City Hospital's renal service:

32. Conference Proceedings.

33. Merrill, Currem Status and Future Prospects in the Treatment of Patients With Chronic Uremia, in Conference Proceedings 37.

34. The medical problems he identified were hypertension, psychiatric problems. metastatic calcification, peripheral neuropathy, and resistant anemia-repeated transfusions that had raised "concern among professional men in the field." Schreiner, Definition of the Problems Imolared in Large-Scale Hemodialysis Treatment, in Conference Proceedings 45.

35. Page. Prolongation of Life in Affluent Soriety, Mod. Med.. Oct. 14, 1963, at 89.

36. Id. (emphasis added).

37. Id. at 91 (emphasis added). 
"Chronic dialysis is properly considered a clinical experiment rather than an established mode of treatment at this time." ${ }^{38}$ Levinsky went on to describe dialysis as a stopgap treatment to keep patients alive while they awaited transplantation or some other form of treatment.

The discussion was not confined to the medical-scientific community but entered directly into the public debate of the issues posed by dialysis and transplantation. In 1965, in hearings before the House of Representatives Appropriations Committee, Congressman Melvin Laird asked a physician witness, Dr. Edward Kass, "Do you consider dialysis a research program or a treatment program?" Kass responded: "I would consider dialysis now at the point in between-I think it's what I would call pilot plan or operational research program." Laird turned to Dr. Theodore Tsaltas, a Philadelphia physician whose own life was being sustained by self-administered hemodialysis treatment, and asked him if he agreed. "I believe that chronic dialysis has gone beyond the actual experimental stage," Tsaltas replied, "and it is now at the point where we can apply it to save lives. The kidney machine is no longer an experiment-it can no longer be classified as an experiment because it works-it is now a scientific fact not a theory-it keeps people alive." 39

Not only did the medical-scientific aspects of the discussion enter the public debate, but political factors affected judgments within the medical-scientific community. ${ }^{41}$ In late 1965, for example, Dr. Neal Bricker, then of Washington University in St. Louis, was elected chariman of the Scientific Advisory Board (SAB) of the National Kidney Disease Foundation. Reflecting the priorities of the research-oriented community, Bricker and the Advisory Board took a series of steps that indicated strong opposition to the endorsement of community dialysis centers by the Kidney Foundation. In October 1965 , Bricker wrote the SAB outlining his future plans and made essentially no mention of dialysis treatment centers. In December, he announced that the Board had voted to discontinue the newsletter "Developments in Dialysis," then being published and distributed under the auspices of the Kidney Foundation. And in January 1966, Bricker and the Advisory Board fired the executive director of the Foundation, who had become controversial through his advocacy of expanding the dialysis treatment centers. Less than three months later, however, the Board considered the legislation sponsored by Senator Jackson, which would substantially expand community dialysis centers, and

38. Crucial Test for Hemodialysis, Mad. World News, Nov. 6, 1964, at 97.

39. Quoted on NBC Television news documentary, Who Shall Live?. Nov. 28, 1965 (paraphrased).

40. These developments are outlined in a letter memorandum from Neal S. Bricker, M.D., to Members of The Scientific Advisory Board, National Kidney Foundation (Feb. 5, 1966). This account has been augmented by interviews with participants and perusal of various documents in their files. 
voted to endorse community dialysis centers. ${ }^{41}$ "What brought us around?" Bricker was quoted as saying. "Reality. The realities are that there is probably going to be an extension and expansion of dialysis activities by Congress, and if the foundation put itself in the opposition, that would be bad." 42

Not until late 1967 , in the report of the Gottschalk Committee, ${ }^{43}$ did both dialysis and transplantation receive "official" medical-scientific sanction as established therapies. The report stated: "The Committee believes that transplantation and dialysis techniques are sufficiently perfected at present to warrant launching a national treatment program and urges this course of action." 44

The lengthy debate indicates that both dialysis and transplantation were evaluated in reference to the experiment-therapy continuum. Consensus was a long time in developing. Among the clinical investigators, Scribner represented the polar extreme of the "physician" committed to providing therapy to dying patients while Levinsky represented the "scientist" given to seeing the limitations of the dialysis procedure. Also suggested is the dimension of conflict, not fully articulated here, between those committed to hemodialysis as a major mode of therapy and those who saw it as basically an adjunct to transplantation.

\section{Other Issues in Treatment Evaluation}

Another issue in the debate within the medical-scientific community was the quality of life provided to patients by these procedures. Were these therapies "life saving" as their proponents argued, conveying to beneficiaries a new lease on normal life: Or were they merely life prolonging, as their critics claimed, creating a number of unresolved clinical problems: On this matter, as well. the medical-scientific community was divided.

A third issue raised by the emergence of dialysis and transplantation, but especially by dialysis, focused on preventive versus treatment approaches to end-stage renal disease. The scientifically oriented members of the community were greatly concerned with the emphasis upon the curative or palliative approach and urged that there be an appropriate research investment into the etiology of end-stage renal disease that would lead to effective means of prevention. The basic weakness of this argument was that it involved a trade-off between the future promise of prevention and the existing reality of treatment. Great uncertainty existed regarding when that promise might be re-

41. Renal Group Eases Policy on Dialysis, MEd. World News, April 8, 1966. at 83.

42. Id.

43. The Gottschalk Committee was established to advise the Bureau of the Budget on a federal policy toward dialysis and transplants. See text accompanying note 72 infra.

44. U.S. Bureau of the Budget. Report of the Comm. on Chronic Kidney disease 2 (1967). 
deemed, and medical scientists advocating the research approach were vulnerable to charges of self-interest in advancing it.

A final issue involved the medical-scientific community's aesthetic evaluation of the therapies. Dr. Lewis Thomas has written of the "high technology" and "half-way technology" of medicine. The former "comes as a result of a genuine understanding of disease mechanisms, and when it becomes available, it is relatively inexpensive, relatively simple, and relatively easy to deliver." Half-way technology, however, is represented by "the kind of things that must be done after the fact, in an effort to compensate for the incapacitating effects of certain diseases whose courses we are unable to do very much about. It is a technology designed to make up for disease or to postpone death." 4.5

Thomas categorizes both hemodialysis and renal transplantation as halfway technologies. Most physicians would agree. Beyond this, especially with respect to dialysis, many would liken the artificial kidney machine to the "iron lung" state of treating poliomyelitis. The poliomyelitis story involved the development of a vaccine capable of preventing this viral disease, a vaccine that made obsolete the clumsy technology of iron lungs. ${ }^{46}$ This experience has had a profound aesthetic attraction for the medical-scientific community. It demonstrates for many the absolute superiority of scientific solutions over technological fixes in medicine. Attitudes toward the artificial kidney, this author believes, have been significantly influenced by the iron-lung analogy.

\section{B. Changing Power Distributions Within the Medical-Scientific Community ${ }^{4}$}

No therapy existed for end-stage renal disease prior to 1960. Those interested in the kidney-its functions and pathologies-were primarily research-oriented medical scientists. The prevailing view of dialysis among the research-oriented members of the medical-scientific community was that the procedure was experimental, the quality of life provided by it was highly unsatisfactory, and it represented the "iron lung" phase of medicine. These views are still prevalent among many medical scientists today.

45. Thomas, Guessing and Knowing: Reflections on the Science and Technology of Medicine, Saturday Rev., Jan. 1973, at 54.

46. The story of poliomyelitis is told in S. BENison, TOM Rivers: Reflections on a L.afe in Medicine and Science (1967); J. Paul. A History of Poliomyelitis (1971): Shannon, NiH Present and Potential Contribution to Application of BioMedical Knowledge. in SENATE Comm. ON Government Operations, Research in the Service of Man: Biomedical Knowledge, Development and Use, S. Doc. No. 55, 90th Cong., Ist Sess. 72 (1967); Benison, The History of Polio Research in the United States: Appraisal and Lessons, in The Twentieth Century Sciences: Studies in The Biography of Ideas 308 (G. Holton ed. 1972); Benison, Speculation and Experimentation in Early Poliomyelitis Research, 10 Clo MEDICA 1 (1975); Weisbrod, Costs and Benefits of Medical Research: A Case Study of Poliomvelitis, 79 J. PoL. ECON. 527 (1971).

47. This section is based on interviews conducted since 1973 with many of the individuals involved in these events. The interpretation is, of course, mine alone. 
In the early 1960s, the medical scientists exercised dominance over all the relevant institutions within which the policy debate over the implications of dialysis and transplantation took place. For instance, within the National Institutes of Health key leadership positions were occupied by research-oriented renal physiologists, and the relevant $\mathrm{N} 1 \mathrm{H}$ study sections were dominated by those who were strongly committed to medical research. The influence of these individuals extended to the major voluntary health associations, including the renal section of the American Heart Association and the National Kidney Disease Foundation (later the National Kidney Foundation).

The research-oriented group was aided for a time by the difficulties that other physicians had in replicating the Seattle results. When Scribner and his colleagues first began using the artificial kidney, Seattle was the only medical center in the country where such treatment was available. Although the Seattle group was successful from the outset in sustaining the lives of patients, other groups in the 1960 to 1962 period had difficulty in efforts to duplicate their experience. Charges were made that Scribner invested so heavily in "tender loving care" for his patients that the Seattle performance did not constitute a scientific test of the new procedure. From the Seattle perspective, failure by others to replicate their successful experience was attributed to a greater orientation toward research than toward patient care or, conversely, the lack of strong interest in establishing long-term hemodialysis as a reality.

From late 1962 through the mid-1960s, a number of young physicians trekked to Seattle to learn how to perform dialysis. Frequently, these younger men were less strongly committed to academic medicine than the renal physiology research community that dominated the scene. These younger physicians believed that lives could be prolonged through hemodialysis and they wanted to participate. The institutional impacts of this were substantial. A program of delivering dialysis therapy to eligible veteran beneficiaries was initiated within the Veterans Administration in 1963, and a number of VA physicians received on-site training in Seattle. Similarly, by the time the Public Health Service initiated a grant program to support center dialysis facilities in 1965, a number of the physicians heading up those twelve grant-supported projects had been to Seattle to learn how to dialyze patients.

It is possible to observe differentiation of the medical-scientific community along four dimensions during the early and mid 1960s. In functional terms, a predominantly research-oriented community now included a significant and growing number of clinicians who were providing dialysis therapy. In terms of age, younger physicians were coming into positions of importance within the kidney disease field. Relative to major medical centers, movement was away from the university research centers and toward treatment-oriented centers located in close proximity to a university medical center. Finally, in specialty terms, nephrology emerged as a clinical and academic specialty alongside the academic specialty of renal physiology. 
A similar pattern can be observed relative to renal transplantation. The surgical techniques of transplantation were established in a few major centers like Peter Bent Brigham in Boston, Medical College of Virginia in Richmond, and the University of Colorado in Denver. ${ }^{48}$ Important differentiation, however, followed the introduction of immuno-suppressive drugs for control of the rejection phenomenon in 1963-1964, and there emerged a number of major "second generation" transplant centers, such as the University of California at San Francisco, Stanford University, and, somewhat later, the University of Minnesota.

What effect did this differentiation have on the policy debate? First, the differentiation of the medical-scientific community occurred as both therapies became increasingly regarded as established, rather than experimental, procedures. Second, the differentiation of the professional community from one dominated by researchers to one having an increased number of clinicians meant that there was a concomitant shift in values from a science-oriented to a patient-oriented view of the clinical situation. Finally, this complex pattern of differentiation meant that there was an increasing number of "identified physicians" distributed broadly across the country who were beginning to interact as constituents with the political-administrative community as participants in the policy debate. In the main, they tended to be advocates for an expanded governmental role.

As professional differentiation occurred with the development of the two therapies, the institutions of medical-science changed also. The 1963 joint American Medical Association-National Kidney Disease Foundation conference constituted an ad hoc arena for discussing the issues that had been raised by Shana Alexander's Life magazine article. The conference was sponsored by the AMA, an organization not known for favoring government intervention in the financing of medical care, and by the Kidney Foundation, which tended to be dominated by its Scientific Advisory Board. Although there was substantial discussion of establishing a series of dialysis research and treatment centers, the conference adjourned without making any recommendations on this matter to the federal government. ${ }^{49}$ The prevailing view was that government intervention was not warranted at that time.

In November 1964, the National Institutes of Health held a conference "to elucidate the technical aspects of hemodialysis in which . . . improvements could be made." 50 Slightly more than forty persons attended and the emphasis was clearly on research. Interestingly enough, two prominent clinicians-Scribner and Merrill-were not present, the former because he

48. F. Moore, Transplant: The Give and Take of Tissue Transplantation 39 (1972).

49. For an indication of the inconclusive nature of the conference, see Conference ProCEEDINGS 65-69.

50. Nat'l Institute of Arthritis and Metabolic Diseases \& Nat'l Heart Institute, Proceedings of the Conference on Hemodialysis I (1964). 
had not been invited. In response, Scribner, with support from a local Seattle manufacturer, hosted a "Working Conference on Chronic Dialysis" one month later, which approximately 160 people attended.51 The composition of this conference and the nature of its agenda indicate a far stronger orientation toward patient-care problems than characterized the NIH meeting.

These three meetings represented ad hoc responses to the need for institutional arenas in which to discuss the problems created by dialysis. Permanent institutional changes were also sought. For example, in 1969 a Medical Advisory Board was created within the National Kidney Foundation, in large measure to offset the research influence of the Scientific Advisory Board. As another example, dissatisfaction in the early 1970s within the American Society for Artificial Internal Organs with the limited portion of the agenda allocated to dialysis and renal transplanation led to the establishment of the Council on Dialysis and Transplantation. This free floating group later attached itself to the National Kidney Foundation.

These changing patterns of organization within the medical-scientific community represent various factors at work. One important element was the manifest desire of clinicians to address the patient-oriented problems of dialysis and transplantation in settings that were not dominated by the research-oriented members of the community. Secondarily, they reflect the desire to establish various platforms from which representations could be made to the political-administrative community. Over time, these changes altered the power balance among scientists and clinicians and led to increased demands for government provision of treatment services from the interested clinician community.

\section{The Gradual Extension of Government Involvement}

In retrospect, one can observe a logical development of federal policy toward both dialysis and transplantation as each emerged from biomedical research and was introduced into patient care. That "logic" can be seen in the contribution of federal policy from research and development, to demonstration and training, and then to capacity-building within the Department of Health, Education, and Welfare.

\section{Research and Development}

The support of biomedical research has long been a widely sanctioned role for the federal government. ${ }^{52}$ In the mid-1960s, soon after dialysis and renal

51. Proceedings of The Working Conference on Chronic Dialysis (1964) (University of Washington).

52. For background on the history of the National Institutes of Health, see S. STRICKLAND, Politics, Science. and Dread Disease: A Short History of United States Medical Research Policy (1972). For an official view of organized medicine on medical research see AmERICAN Medical Ass'n, Report of the Commission on Research (1967). 
transplantation appeared, supporting research programs were established within the National Institutes of Health.

The possibility of using immuno-suppressive drugs to control the rejection by the host of a transplanted kidney was suggested to the scientific community in 1959 and was taken up quickly by medical scientists engaged in experiments with kidney transplantation. ${ }^{53}$ The first application to humans was in 1961. Within a short time, control of the immunological rejection phenomenon in kidney transplantation by immuno-suppressive drugs had displaced the earlier use of whole-body irradiation in clinical research. In 1964, as a result of this work, the Committee on Appropriations of the House of Representatives added two million dollars to the budget request of the National Institute of Allergy and Infectious Diseases "to start a real program in the study of immunological defense mechanisms as they relate to the rejection, by one person's body, of transplanted tissues from the body of another person." 54 The Senate Appropriations Committee, in that same year, concurred. "This rejection phenomenon," it noted, "rather than surgical technique, is today the most serious obstacle to successful organ transplants." "is The Transplant Immunology Program, within the National Institute of Allergy and Infectious Diseases, was established in direct response to the implications of research results and in an effort to pursue those implications.

The establishment of the Artificial Kidney/Chronic Uremia Program within the National Institute of Arthritis and Metabolic Diseases occurred more slowly. Scribner testified in 1962 about the need for research funds to improve hemodialysis, and the Senate did add an additional one million dollars to the Institute's fiscal 1963 budget request "for expanded research in diseases of the kidney." "It also recommended that "a considerable portion" be devoted to further research on the artificial kidney. Although the 1962 Senate Appropriations Committee report described hemodialysis as a "brilliant triumph of medical research, $"{ }^{5}$ its 1963 report more modestly referred to it as "an excellent example of practical accomplishment." 58 Neither the Senate nor House appropriations committee saw fit in either fiscal 1964 or 1965 to take additional action.

Substantial pressures were brought to bear upon the Congress, the National Institutes of Health, and the executive branch during these vears to create a program of research on the artificial kidney. Finally, in connection with the fiscal 1966 appropriation, the House recommended two million dollars more than the budget request from the Arthritis and Metabolic Disease

53. F. Moore, supra note 48 , at 128-65

54. H.R. ReP. No. 1316, 88th Cong., 2d Sess. 35 (1964).

55. S. REP. No. 1460, 88th Cong., 2d Sess. 54 (1964).

56. S. ReP. No. 1672, 87 th Cong. 2d Sess. 40 (1962).

57. Id. at 39 .

58. S. ReP. No. 383, 88th Cong., 1st Sess. 57 (1963). 
Institute, for "the development of a better artificial kidney than the machines which now exist." 59 The Senate Appropriations Committee, impressed with the need for "simpler and less costly techniques," added an additional one million dollars to the House allowance to enable research and development work to proceed "with all possible speed." 60 But the evidence indicates a program of research and development for a better dialysis machine was not established quickly.

\section{Demonstration and Training}

A thornier policy question arose in connection with funding dialysis centers through Public Health Service funds. Scribner and his colleagues in Seattle had established a community treatment center in 1962. Through a combination of support from private philanthropy and community fund-raising, an active dialysis center was in existence when the 1962 Life magazine article appeared. In 1963, a Public Health Service grant was made to this center to assist it in meeting its financial obligations. ${ }^{61}$

The policy discussion generated by this grant dealt with several considerations, two of which were addressed by the Senate Appropriations Committee in its report on the fiscal 1965 appropriation. First, the committee pointed out, chronic illness and aging formula grant funds were available "for the States to use at their discretion for the support of community dialysis centers"; furthermore, the Public Health Service had the authority under the Community Health Services and Facilities Act of 1963 to use funds for community dialysis centers. Second, the committee report made clear that such funds were legitimate for demonstration and training but not for payment for treatment of illness. ${ }^{62}$

There was an underlying issue that troubled the Senate Appropriations Committee. The two grants that had been awarded before 1964, one to Seattle and the other to Downstate Medical Center in Brooklyn, were step-funded over a three year period so federal funds would be phased out during that time. It was assumed by Public Health Service officials that community financial support would be established at the end of the three years. The Senate, especially Senator Lister Hill of Alabama, was skeptical that community support would be forthcoming. In 1964, the committee indicated that it had decided against an amendment proposed by Senator Henry M. Jackson of Washington to provide one million dollars for two additional centers. ${ }^{63}$

59. H.R. Rep. No. 272, 89th Cong.. lst Sess. 17 (1965).

60. S. ReP. No. 537, 89th Cong., Ist Sess. 56 (1965).

61. See Senate Comm. on Appropriations, Dep't of labor, and Health, Education and Welfare and Related Agencies Appropriations Bill, 1965, S. Rep. No. 1460, 88th Cong., 2d Sess. $17-18$ (1964).

62. S. Re.P. No. 1460, 88th Cong., 2d Sess. 19-20 (1968).

63. Id. at 20 . 
In 1965, in connection with the fiscal 1966 appropriation, the House Appropriations Committee recommended an additional two million dollars beyond the budget request of $\$ 1.4$ million for supporting hemodialysis centers. The committee's report noted that this amount fell short of the five million dollars recommended by the Public Health Service advisory groups. The Senate committee concurred with the House in providing a total of $\$ 3.4$ million for the support of fourteen community dialysis centers. ${ }^{64}$

The members of the House and Senate Appropriations Committees, where much control over federal government health policy resided in the 1960s, knew what they were doing. They were prompted to action in 1965, in part, by the knowledge that NBC Television was preparing, for release that fall, a documentary program which would contrast the millions of dollars being spent on the space program with the government's apparent unwillingness to spend money to save lives on earth. ${ }^{65}$ However, the Senate, in setting forth the legal authority for Public Health Service action, limiting the scope of that action to demonstration and training, and providing modest funds for fourteen community dialysis centers, showed a fundamental unwillingness to accept federal government responsibility for paying for the costs of treatment.

Indeed, the federal government moved to further limit its involvement in community dialysis centers in 1968 and 1969. The Health Service and Mental Health Administration, under whose authority the kidney centers program was then being administered, took action to terminate grant support. A May 1969 memorandum from the director of the Kidney Disease Control Program to the Administration indicated that support had terminated for four centers, one other center was soon to go off federal funding, fourth year funding extensions to the original three year grants had been negotiated with seven centers on the condition that this support was to be terminal, and fourth year support was not anticipated for two other centers. ${ }^{66}$

\section{Capacity-Building}

The development of hemodialysis centers around the country led to a stream of legislative proposals for expanding federal government programs from 1965 onward. Senator Jackson was the foremost advocate of such legislation in the Senate; Representative Roybal, among others, in the House. But this flurry of proposed legislation literally went nowhere. No hearings were held on any legislation during the period from 1965 through 1969. All con-

\footnotetext{
64. S. REP. No. 537, 89th Cong., lst Sess. 56 (1965).

65. NBC Television news documentary, supra note 39

66. Memorandum from David S. Hathaway, Surgeon, Acting Chief, Kidney Disease Control Program to Administrator, Health Services and Mental Health Administration through Acting Director, Division of Chronic Disease Programs, RMPS, Director, Regional Medical Programs Service, Fourth-Year Funding-Chronic Hemodialysis Grants (May 20, 1969).
} 
gressional action was effectively confined within the appropriations committees.

Reluctance to see an expanded role for the federal government in hemodialysis was not limited to the legislative branch. In early 1969, the director of the Regional Medical Programs Service, in a memorandum to the deputy administrator of the Health Services and Mental Health Administration, wrote in response to a request for comments on proposed legislation to support treatment of end-stage kidney disease: ${ }^{67}$

I judge that the major question we should ask ourselves as we review the proposed legislation is this: "Can we and should we at this time make an all out effort to establish facilities for the treatment of all patients with end-stage kidney disease who can benefit from hemodialysis?" My answer is no.

After recommending a strategy directed at prevention, early detection, and early treatment of kidney disease, this official described the proposal to finance treatment of end-stage renal disease through Social Security as "quite unsound." He cogently summarized his views on the central issue: ${ }^{68}$

Our present system of health care controls costs in cases like this by setting up barriers to adequate care by making accessibility and financing difficult or impossible. The cost in dollars, facilities, and health manpower of a national kidney program which would remove these barriers to patients with end-stage kidney disease are so great that for the time being we may have to leave them erect.

Kidney disease legislation was finally enacted in 1970. The legislative authority for the Regional Medical Programs Service was amended to read, "The Heart Disease, Cancer, Stroke, and Kidney Disease Amendments of 1970."69 The HEW kidney disease program initiated in the chronic diseases division of the Public Health Service in 1965 was now legally lodged in the Regional Medical Programs Service, where it had been administratively lodged since 1969. This legislation established a means whereby community dialysis centers could receive financial support through the fifty-five regions of the Service. Policy control was centralized, but funds for centers were allocated on a decentralized basis through the regions. The net effect of this arrangement was to increase dialysis capacity at the local community level, even though there remained great reluctance at the highest levels of the federal government to adopt legislation that would provide directly for patientcare financing.

The apparent progression from research and development through dem-

67. Memorandum from Stanley W. Olsen, M.D., Director, RMPS to Irving Lewis, Deputy Administrator, HSMHA, Comments on Proposal for Legislation to Support Treatment for EndStage Kidney Disease (April 22, 1969).

68. Id.

69. Pub. L. No. 91-515, § 101, 84 Stat. 1297 (1970) (emphasis added). 
onstration and training to capacity-building is obviously a reconstruction of events. The "technical logic" of HEW policy development looks more rational in retrospect than it did at the time. It is true, however, that federal health policy within the statutory framework of the Public Health Service Act was primarily oriented toward medical research while concurrently engaged in a search for effective means to bring the results of research into medical practice. Within this framework, policy consistently stopped short of assuming a federal government role for payment of patient treatment costs. Policy toward end-stage renal disease was clearly constrained by these broader considerations.

\section{The Veterans Administration}

The United States Government did assume responsibility for financing treatment for veterans who were eligible for medical benefits from the Veterans Administration. In 1963, the VA announced the initiation of a program to establish dialysis units in thirty VA hospitals around the country. ${ }^{70}$ This was done over the next few years and by July 1, 1972, the VA was dialyzing 16 per cent of the total reported dialysis patients in the country. ${ }^{i 1}$

The VA reached the decision to provide dialysis treatment largely within its own organization. It did request apportionment of construction funds for refurbishing hospitals to create dialysis units, however, from the Bureau of the Budget in 1965, a request which prompted much discussion within the Bureau about its implications. Consultations between Budget officials and the Office of Science and Technology led to a decision, implemented in 1966, to establish a committee of experts to advise the Bureau on government-wide policy toward dialysis and transplantation. This group, known as the Gottschalk Committee, after its chairman, Dr. Carl W. Gottschalk, of the University of North Carolina, issued its report in September $1967 .{ }^{72}$ Among other things, the report provided the Bureau of the Budget with a basis to urge combined dialysis and transplantation units within VA hospitals and to promote home dialysis-a less costly mode of treatment-as an alternative to hospital-based dialysis. The legal basis of VA action in providing dialysis treatment was clear. To reverse the VA policy decision once it had been made would have been a momentous political task. Even so, the VA action was scrutinized by the Bureau of the Budget and stimulated that agency to explore more fully the policy implications of available treatment for end-stage renal disease.

70. Conference Proceedings 67.

71. Research Triangle Institute, Nat'l Dialysis Registry: Fourth Annual Progress RePORT, supra note 11 , at $5,14$.

72. U.S. Bureal of The Budget, supra note 44. 


\section{The Evolution of the Federal Goverment's Role in Health}

The policy debate on payment for treatment of end-stage renal disease parallelled the larger debate about the appropriate role of the federal government in the provision of health services generally. This larger debate, moreover, occurred not with respect to the Public Health Service or the Veterans Administration but with respect to the Social Security system. In 1965 , Congress added titles XVIII and XIX to the Social Security Act, ${ }^{73}$ thus establishing Medicare and Medicaid programs and the principle that the aged and indigent deserved government-financed health insurance. This major initiative in federal health policy was necessary, but not sufficient, to provide a statutory basis for patient-care financing for end-stage renal disease.

In 1967, the Gottschalk Committee recommended financing patient care for end-stage kidney disease patients through an amendment to title XVIII (Medicare) of the Social Security Act. ${ }^{74}$ The Committee argued that the Johnson administration's recommendation that the disabled be aided should be the basis for payment for kidney disease patients, although the disability recommendation was not enacted in 1967. The disability recommendation did result, however, in the undertaking of a study within the Social Security Administration in 1968. This study laid the groundwork for providing Medicare health insurance benefits to the most severly disabled. ${ }^{75}$ The provision of such benefits did not actually occur, however, until the passage of the Social Security Amendments of 1972, the same legislation that included section 299I. ${ }^{76}$

The language of section 299I reflects the importance of this expansion of the federal health insurance role. After stipulating the conditions of eligibility - under sixty-five, fully or currently insured or entitled to monthly benefits, medically determined to have chronic renal disease-the provision said such individuals shall be deemed to be disabled for purposes of coverage under Medicare. It is unclear what formula would have been used for renal diseases if the expansion of Medicare benefits to the disabled had not been occurring simultaneously.

Senator Russell B. Long, chairman of the Senate Finance Committee, was then, as now, advocating health insurance for catastrophic illness. Kidney disease was seen as a catastrophic illness, severly depleting or exhausting the

73. See T. Marmor, The Politics of Medicare (1970).

74. U.S. BuREau of THE Budget, supra note 44 , at $1,14,85-99$. The committee was asked to do a cost-effectiveness study of how to provide treatment, not a cost-benefit study of whether to provide it. Bureau of the Budget officials saw the former question as one to which experts could bring their competence, but the latter was a matter to be decided by senior policy officials. One factor apparently motivating the Bureau was that a program for dialysis was seen by it and the White House as a potential post-Vietnam spending initiative if peace should break out. Interview with Carl W. Gottschalk, M.D., in Chapel Hill, North Carolina (April 16, 1975).

75. Advisory Council on Health Insurance for the Disabled, Health Insurance for the Disabled Under Social Security (1969)

76. WAYS AND MEANS, BaCKGround INFORMATION 2-6. 
financial resources of nearly all of those who required therapy. ${ }^{77}$ Therefore, in addition to being included under the general language of the disability provision, financing of treatment for end-stage renal disease was also seen as the first step toward providing catastrophic medical insurance through Medicare.

As long as kidney disease programs were authorized and funded under the authority of the Public Health Service Act, it was possible to confine the government's responsibility to activities that stopped short of patient-care financing. To bridge the gap, it was necessary to shift the context of the policy debate from that framework to that provided by Title XVIII of the Social Security Act, but even this was not sufficient to ensure the commitment made in section 299I. The ability of the Congress and its staff to relate end-stage renal disease to disability and prospectively to catastrophic health insurance was also necessary.

\section{E. The Importance of Identified Lives}

The policy debate which preceded the enactment of section 2991 does not reveal an automatic reflexive response by the government to the victims of end-stage renal disease. Rather, it suggests a "tipping process" at work. ${ }^{78}$ It was necessary for the cumulative effect of an increasing number of government programs to be felt, as discussed above. Moreover, it appears that widespread publicity of lives lost for the lack of scarce medical resources was necessary, including specific dramatization of identified lives at stake. Finally, the number of patients being kept alive had to increase to the point where they simply could not be ignored.

During the 1960 s and early 1970 s a substantial stream of newspaper and television coverage publicized the plight of individuals with end-stage kidney disease. Two major, early examples are the 1962 magazine article and 1965 NBC documentary mentioned above. Scribner thought that the effects of this publicity would be immediate and would generate intense public demand for a strong federal government commitment to providing treatment for those with chronic kidney failure. The limited response in both cases came as a great surprise to him. ${ }^{79}$ The effect of such publicity was obviously cumulative, not immediate, in its influence on policy.

77. 118 CoNG. ReC. 33008 (1972).

78. Tipping refers to the process which is said to occur "when some recognizable minority group in a neighborhood reaches a size that motivates the other residents to begin leaving." See Schelling, A Process of Residential Segregation: Neighborhood Tipping, in Racial Discrimination in Economic Life 157 (A. Pascal ed. 1972). See also T. Schelling, Models of Segregation (1969). The concept, as applied here, refers to the cumulative process by which a series of incremental policy changes lead to a threshold-crossing major change as was the case in the enactment of section 2991.

79. Interview with Belding H. Scribner, M.D., Seattle, Washington (Aug. 8, 1966). 
Publicity included dramatization of particular identified lives. In 1965, Dr. Theodore Tsaltas, the Philadelphia physician who was dialyzing himself, testified, with substantial emotional impact, before the House Committee on Appropriations, testimony later seen on the NBC TV documentary. ${ }^{80}$ In 1966, on a visit to Seattle, Representative John E. Fogarty, chairman of the House committee, observed a patient dialyzing himself in his home. A New York City resident testified and was dialyzed before the House Ways and Means Committee in November $1971,{ }^{81}$ a demonstration which apparently contributed to the willingness of Representative Wilbur Mills to support a kidney disease amendment to Medicare. ${ }^{82}$ Without question, the publicity and dramatization of these identified lives affected the policy debate, although the extent of their influence with legislators at any given time is unclear.

The number of patients undergoing dialysis grew steadily prior to the 1972 legislation. The Gottschalk Committee had data on 247 individuals who had begun dialysis treatment in Public Health Service supported programs from 1960 to March 1967, of whom forty-two, or 17 per cent, had died. ${ }^{83}$ The committee estimated that this number amounted to one-fourth to onethird of all those who had begun treatment since 1960, indicating a total of 750 to 1,000 patients. Using the 17 per cent mortality rate, the estimate was that approximately 620 to 830 dialysis patients were alive in March 1967. Data from the National Dialysis Registry indicate that the number of patients being kept alive on dialysis had increased to 2,874 by June 30,1970 and to 5,786 two years later. ${ }^{84}$

An interesting question for future research is: When and under what circumstances does the number of identified lives become so large that patientcare financing becomes an imperative? As noted earlier, the victims of some other deadly conditions including, most notably, hemophiliacs, have not been treated as generously by the government as the victims of end-stage renal disease.

\section{F. The "Sotto Voce" Character of the Policy Debate}

Though the plight of the victims of chronic kidney failure was kept before the public by both local and national newspapers, magazines, and broadcast

80. Hearings Before a Subcomm. of the House Comm. on Appropriations, 89th Cong., 1st Sess., pt. 4, at 605 (1965) (statement of Dr. Theodore Tsaltas).

81. Hearings on National Health Insurance Proposals Before the House Committee on Ways and Means, 92d Cong., 1st Sess., pt. 7, at 1524-46 (1971) (statement of Shep Glazer, Vice President, National Association of Patients on Hemodialysis).

82. Interview with Charles L. Plante, Washington, D.C. (July 12, 1973), and William Fullerton, Washington, D.C. (July 12, 1973).

83. U.S. Bureau of The Budget, supra note 44, at 47-49. The Committee also had data on 231 Veterans Administration patients who had begun dialysis since 1963, of whom forty-seven had died at the time of the report.

84. Research Triangle Institute, supra note 11. 
media, the policy debate per se was not very public in character. The issues in the debate were clearly understood and vigorously discussed, as indicated above, but the debate itself had low public visibility and limited public participation. Let us summarize the above discussion in this regard.

All the policy issues were extensively discussed within the medical-scientific community. The settings for these discussions were controlled by the medical, scientific, and voluntary health organizations concerned with renal disease. These organizations were dominated by the research community in the early 1960 s, but clinicians came to play an increasingly important role as time passed. Nevertheless, these discussions within the medical-scientific community were basically inaccessible to the public.

Congressional discussions of the issues posed by end-stage kidney disease were confined for many years to the appropriations committees of the House and Senate. Existing legislative authority was deemed adequate for the range of acceptable policy responses until 1970. No kidney disease legislation was enacted until that year, though numerous bills were proposed from 1965 onward. Nor was there any full discussion of the issues in congressional committee hearings on kidney disease during the policy debate. Not even the 1972 legislation, as we shall see in a moment, received thorough legislative attention.

Executive branch discussions of the policy issues were often focused on specific budgetary questions, matters of very low public visibility. The various legislative proposals introduced in the Congress generated important analyses within the executive branch, but the absence of legislative hearings meant that the positions developed were never publicly articulated. The effort to address the policy issues through the Gottschalk Committee, moreover, was deliberately kept at a very low profile and the release of its report to the public was done in an almost surreptitious manner. ${ }^{85}$ The executive branch displayed no enthusiasm at all for a public discussion of the issues.

The policy debate on patient-care financing for kidney disease was carried out mainly within the inner councils of the medical-scientific community and the political-governmental system. Two explanations are suggested for this "sotto voce" character of the debate. One hypothesis is that there existed a basic asymmetry in the relative power of the opponents and proponents of federal government financing of treatment costs with opponents controlling access to the formal decision-making agenda of government for an extended time and thus able to prevent the issue from being considered. Alternatively, it is possible to argue that both opponents and proponents were reluctant to have this issue fully considered in a public debate, fearing perhaps that it was too divisive for the polity to handle. The evidence supports both propositions

85. See Blamphin, Capital Rounds, MED. World News, Nov. 24, 1967, at 77 
to some extent, suggesting that this particular "value of life" issue posed great difficulties for the normal functioning of policy formation processes.

\section{IV \\ Resolution of the Debate}

This analysis has discussed a number of the factors which influenced the extended policy debate on patient-care financing for end-stage renal disease. The evidence reveals great reluctance by the government to assume the financial responsibility for paying patient treatment costs. In 1972 the policy debate was finally and suddenly resolved.

In early 1971, at the outset of the Ninety-second Congress, the Nixon Administration proposed a number of major amendments to the Social Security Act. The bill which was introduced in the House of Representatives as H.R. 1 dealt with consolidation of fifty-four federal-state programs for the needy aged, blind, and disabled; the establishment of more effective cost controls on Medicare and Medicaid; the provision of health care to Medicare and Medicaid recipients through health maintenance organizations; and various modifications of the Social Security benefit structure. ${ }^{86}$ But "by far the most significant and the most needed provisions of H.R. 1," in the words of Elliott Richardson, then Secretary of Health, Education, and Welfare, were "those which reform the family welfare system and replace it with a new national program." 87

The welfare reform debate was very protracted, especially in the Senate. ${ }^{88}$ In addition to the Nixon Administration's proposal, Louisiana Senator Russell B. Long, chairman of the Finance Committee, was advocating a more conservative welfare reform bill ${ }^{89}$ and Senator Abraham Ribicoff of Connecticut was proposing a more liberal version. ${ }^{90}$ None of the three parties had the votes to prevail over the other two, nor were any two able to compromise differences. By midsummer 1972 , it was clear that welfare reform legislation had effectively been killed.

The prolonged debate on welfare reform had consumed so much time that passage of any bill was threatened. Since H.R. 1 contained many important provisions apart from welfare reform, no one wished the Congress to fail in enacting legislation. This commitment to pass some kind of bill was reinforced by the desire to avoid the experience of 1970, when the House had

86. S. Rep. No. 1230, 92d Cong., 2d Sess. 19 (1972) for the bill as it came to the Senate floor.

87. Hearings on Social Security Amendments of 1971 Before the Senate Comm. on Finance, 92d Cong., lst Sess., pt. 1, at 30 (1971).

88. See M. Bowler, The Nixon Guaranteed Income Proposal: Substance and Process in Policy Change (1974).

89. See S. ReP. No. 1230, 92d Cong., 2d Sess. 449-500 (1972).

90. See id. at 1247-82. 
refused to meet with the Senate in a joint conference committee late in the session because there was so little time to negotiate important differences prior to the November election. ${ }^{91}$ This time, both House and Senate were determined to have legislation on the President's desk before election day, November 7, 1972.

At no point in the extensive hearings on H.R. I did either the House or the Senate hear testimony on renal disease. It is true, however, that in November 1971 the House Ways and Means Committee, in connection with hearings on national health insurance, heard testimony which urged that end-stage renal disease be included in any such program. ${ }^{92}$ Moreover, in December, Representative Mills introduced a bill that would have amended the Social Security Act to provide patient-care financing for chronic renal disease patients, ${ }^{93}$ a bill more notable for signaling $\mathrm{Mr}$. Mills's intentions than for the care with which it was drafted. But neither the Ways and Means Committee hearing nor Mills's legislative proposal was part of the legislative history of H.R. 1. Furthermore, there was no activity within the Senate Finance Committee during this time which remotely related end-stage renal disease to H.R. 1 .

The end-stage renal disease amendment was not considered until the provisions of the entire H.R. 1 bill were being debated seriatim on the Senate floor. On September 30, as indicated at the beginning of this article, Senator Vance Hartke proposed an amendment on chronic renal disease. His proposal was accepted with little debate by the Senate and with a slight change in one provision by the House and Senate conference committee. After the Senate and House approved the conference committee report, President Nixon signed H.R. 1 on October 30, 1972.

A number of interesting arguments were raised in the Senate floor debate, most of them by Senator Hartke. He argued that the nation spent billions for transportation, outer space, defense, cosmetics, and appliances, "but when it comes to maintaining our health, we revert to the primitive values and attitudes of the distant past." ${ }^{4}$ A tragic irony of the 20th century was that people were dying because access to proper medical care was limited by cost. An extension of that irony was that medical research had produced "two proven lifesaving therapies for terminal patients," but that only a small percentage of the potential beneficiaries received them. ${ }^{95}$ The fundamental question was this: "How do we explain that the difference between life and death

\footnotetext{
91. Interview with Irwin Wolkstein, Bureau of Health Insurance, Social Security Administration, Baltimore, Maryland (Sept. 10, 1973).

92. Hearings on National Health Insurance Proposals Before the House Comm. on Ways and Means, 92d Cong., 1st Sess., pt. 7, at 1524-46 (1971).

93. See H.R. 12043, 92d Cong., 1st Sess. (1971).

94. 118 Cong. Rec. 33003 (1972).

95. Id
} 
is a matter of dollars? How do we explain that those who are wealthy have a greater chance to enjoy a longer life than those who are not?"96 The Senator's recommendation was to "begin to set our national priorities straight by undertaking a national effort to bring kidney disease treatment within the reach of all those in need." 97

The central issue was reiterated by several other Senators. Senator Jackson, Democrat of Washington, thought it was-"a great tragedy, in a nation as affluent as ours, that we have to consciously make a decision all over America as to the people who will live and the people who will die."98 He recalled the Seattle experience in allocating scarce dialysis machines, and believed that the nation could do better. Senator Chiles, Democrat of Florida, honorary chairman of the Florida Kidney Foundation, Inc. that year, reiterated the same point: ${ }^{99}$

... in this country with so much affluence, to think that there are people who will die this year merely because we do not have enough of these machines and do not have enough dollars, so that we do have to make the choice of who will live and who will die, when we already know we have a good treatment that can succeed and keep these people alive, while we are working out other improvements in transplants, finding cures, and everything else necessary. This should not happen in this country.

The notable point was that the reluctance to sacrifice lives for dollars was articulated not as an absolute value, but as one that bore some relation to national wealth or affluence.

Still, proponents of the amendment were not indifferent to the costs of treatment. Senators Hartke, Jackson, and Magnuson, Democrat of Washington, all suggested that the costs of dialysis would continue to go down with new advances in the technology of the artificial kidney. Hartke also argued for kidney transplantation in glowing terms and looked forward to substantial cost reductions for this surgical procedure. Costs of dialysis, moreover, could be offset in Hartke's view by the prospect that 60 per cent could return to work with retraining while "most of the remaining 40 per cent need no retraining whatsoever." ${ }^{100}$ In short, there was reason to be optimistic in unit cost terms.

Aggregate costs to the nation, moreover, were seen as manageable. Preliminary estimates, Hartke indicated, were that first year costs would be about $\$ 75$ million, and the fourth year cost about $\$ 250$ million. He also suggested that the $\$ 90$ to $\$ 110$ million the amendment would cost annually "is a minor

\footnotetext{
96. Id.

97. $I d$.

98. Id, at 33007 .

99. Id. at 33008 .

100. Id. at 33004 .
} 
cost to maintain life." He did not reconcile these differing numbers. "It is possible," he suggested, "that these costs could be covered by the slight actuarial surplus in the hospital insurance trust fund and the slight reduction in costs now estimated for the regular medicare program for the disabled." ${ }^{101}$ But if a medicare tax increase "of a small amount is necessary, it would be quite normal," he said. ${ }^{102}$

Senator Wallace Bennett, Republican of Utah, was the only one who spoke in opposition to the amendment. He thought the Senate was about to vote $\$ 100$ million to $\$ 250$ million for dialysis and transplantation, but presented no more justification for his figures than did Hartke. He argued that the amendment, like various other amendments added the previous day, overloaded the bill, represented "Christmas in September," and was "an additional straw that will break the back of the social security system."103 Bennett also argued that the amendment was the "wrong vehicle." Kidney disease was being singled out for special treatment. "A more reasonable way to handle this amendment," the Utah Republican argued, "would have been to delay action until it can become part of a broader health insurance bill." 104

Senator Russell B. Long, Democrat of Louisiana and floor manager of H.R. 1 in his role as chairman of the Senate Finance Committee, responded to Bennett's last argument. ${ }^{105}$

The next Congress will tackle health insurance issues, and I am sure during that debate we will deal with health insurance problems in general, and I hope that specifically we will deal with the problem of insuring against catastrophic illness. I am cosponsoring this proposal at this time because these very unfortunate citizens with chronic renal failure cannot wait for Congress to debate these broader issues. They need help-it is critical-and that help must come now as many of them, without assistance, simply will not be alive for another two years.

The medical means to deal with end-stage renal disease were at hand. One should not, under such circumstances, pass up a legislative opportunity to act.

On January 11, 1973, Richard D. Lyons, a New York Times reporter, challenged the cost estimates that Hartke had used in the Senate debate. Based on information supplied by HEW officials, ${ }^{106}$ Lyons wrote: ${ }^{107}$

Original cost estimates ranged from $\$ 35$ million to $\$ 75$ million in the first fiscal year of operation. The debate record in both houses shows that the highest estimate was $\$ 250$ million in the fourth year. Yet calculations made by

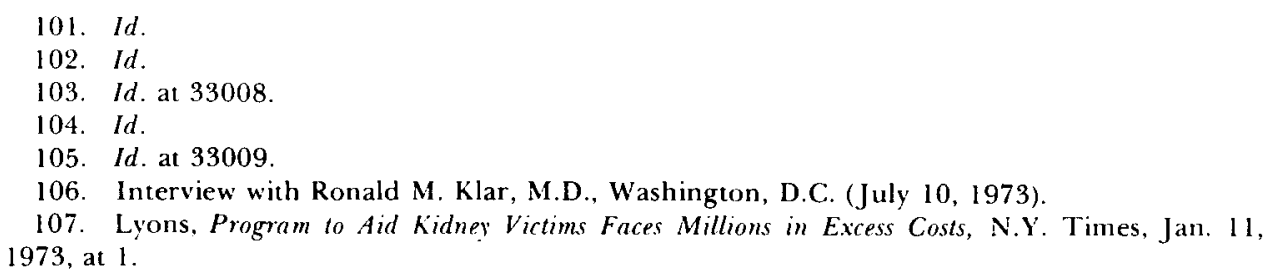


Federal experts after passage set first year costs at $\$ 135$ million, rising to $\$ 1$ billion annually a decade from now.

Lyons quoted several prominent Senators and Representatives to the effect that they would not have supported the provision had they known the full magnitude of the anticipated costs.

This story was the basis for a Sunday editorial-"Medicarelessness"- on January 14, 1973, in which the New York Times criticized Congress for not knowing what it was doing and for not recognizing the implications of its decision. ${ }^{1108}$

The point is not that victims of renal disease are unworthy of help, but that Government resources have to be allocated to meeting many needs. If a billion dollars has to go to prolonging the lives of thousands of kidney disease victims, that is a billion dollars that cannot go to eradicating slums, improving education or finding a cure for cancer.

The editorial concluded by stating that "society has a right to expect that the legislators will understand what they are doing and know the magnitude of the commitment they are making when they pass special interest legislation, whether for kidney disease sufferers or anybody else."

The implication that Congress was not fully informed in its action, though challenged by the National Kidney Foundation, ${ }^{109}$ has achieved some currency. A 1975 report by the Subcommittee on Health and the Subcommittee on Oversight of the House Ways and Means Committee developed the data cited above in Table II on incurred costs of the end-stage renal disease program, costs substantially greater than estimated by Senator Hartke. ${ }^{110}$ A more recent report by the Subcommittee on Oversight explicitly juxtaposed the estimates for section 299I only, which were available to the conferees and those then available to the subcommittee for the third and fourth years of the program in the manner demonstrated by Table III. ${ }^{11}$ The costs of section 299I, it should be remembered, are estimated to be only 60 percent of all Medicare renal costs. The estimated incurred costs for all renal patients for fiscal years 1976 and 1977 were $\$ 500$ million and $\$ 600$ million respectively, a far cry from Senator Hartke's original estimates.

Did Congress know what it was doing when it passed section $299 \mathrm{I}$ as part of H.R.1? It is clear that the Congress was wrong on the cost estimates of the end-stage renal disease provision. It is also the case that it did not inform

108. Medicarelessness, N.Y. Times, Jan. 14, 1973, at 16, col. 1.

109. Altman, Kidney Foundation Criticizes Articles on Care Cosis, N.Y. Times, Jan. 18, 1973, at 30, col. 5 .

110. WaYs and MEans, Background Information 15

111. House Comm. on Ways and Means, 94th Cong., 1st Sess., Report on Administration by the Social Security Administration of the End-Stage Renal Disease Program Established by Public Law 92-603 (with additional views) and on the Social Security Medicare Research Studies 2 (Comm. Print 1975). 
TABLE III

Estimated Incurred Costs of Section 2991

Third and Fourth Years

\begin{tabular}{ccc} 
& 1972 & 1975 \\
\hline Fiscal Year & $\begin{array}{c}\text { Data available } \\
\text { to conferees } \\
\text { (cash disbursement) }\end{array}$ & $\begin{array}{c}\text { Revised } \\
\text { latest estimate } \\
\text { (incurred cost) }\end{array}$ \\
\hline 1976 & $\$ 198,000,000$ & $\$ 300,000,000$ \\
1977 & $\$ 252,00,000$ & $\$ 360,000,000$ \\
\hline
\end{tabular}

Source: House Comm. on Ways and Means, 94th Cong., lst Sess., Reports on Administration by the Social Security Administration of the End-Stage Renal Disease Program Established by Public law 92-603 (with Additional Views) and on Social Security MediCare Research Studies 2 (Comm. Print 1975).

itself on the immediate issues through the process of legislative hearings on the proposed amendment. But the lengthy policy debate on patient-care financing was one to which many members of Congress had contributed. And the Congress had received information on the need for financing patient-care costs for kidney disease from the National Kidney Foundation, especially since 1969 when Dr. George E. Schreiner became president of the N.K.F. and hired Mr. Charles Plante to represent its interests on Capitol Hill. ${ }^{12}$ Senator Long, moreover, had introduced catastrophic health insurance legislation in 1970 and had been persuaded that end-stage renal disease was a special case requiring catastrophic coverage well before September 1972. The Congress, though perhaps not fully informed, was hardly without knowledge of the central issues.

Are there circumstances under which the outcome might have been different? One can only speculate, but three situations deserve mention. First, if there had been a thorough set of legislative hearings on the inclusion of endstage renal disease under Medicare coverage, a few votes on the provision itself might have been changed. Whether the vote might have gone in the other direction is impossible to say, but it is not likely that the provision would have been defeated. Thorough hearings, however, would have deprived the Times of much of the basis for its criticism. They also would have precluded the development of Congressional grumbling, like that of the House Ways and Means Committee, that a major, threshold crossing, precedent setting decision was made in a casual legislative manner. Second, if better information had

112. The Kidney Care Issue: A Test for National Health Insurance, 8 Hosp. Practice, April 1973, at 40, 49-52, 59 . 
been available on unit costs of therapy and aggregate costs to the Medicare program, more Senators and Representatives would have paused before approving the amendment. It is easier to imagine that good cost information would have had a greater effect than thorough legislative hearings alone might have had, but again the impact on final outcome is speculative. Finally, had the debate taken place in 1974, rather than in 1972, when the country was in the midst of a severe recession, or in 1975, when concern for the short-term and long-term financial viability of the social security system was high, the concerns of Senator Bennett would have produced greater resonance among other legislators. Whether these three conditions, singly or in combination, might have resulted in a different outcome, however, is simply a matter of conjecture.

\section{V}

\section{Policy Implications}

How does this analysis of the policy debate on financing treatment for victims of end-stage renal disease bear upon the proposition that society is unwilling to sacrifice identified lives for dollars? Zeckhauser has argued that the 1972 legislation establishing Medicare benefits for end-stage renal disease was an instance of this reluctance. His formulation, quoted at the outset, is worth quoting again: ${ }^{113}$

When risks of lives are involved, an important valued belief is that society will not give up a life to save dollars, even a great many dollars. Rarely is this belief, widely held albeit mistaken, put to a clear test. When it is, it may be desirable for society to spend an inordinate amount on each of a few lives to preserve a comforting myth. Such a myth-preserving action was taken when the federal government assumed the costs of renal dialysis.

In the policy debate preceding enactment of Section 299I, the argument was frequently made that life-saving therapy should not be denied because of lack of money-and without doubt this argument was a powerful one. Its power, however, should not be overestimated: only after more than a decade of debate was a treatment payment program finally approved.

Over the entire length of the protracted debate there were always strong voices of opposition to a treatment payment program. These voices were found within the medical-scientific community, the executive branch, and the legislative branch. Their opposition is eloquent testimony to the fact that policy makers are not always prepared to save lives at any cost. This opposition often made its case in "sotto voce" fashion and argued against a treatment payment program in some indirect fashion, e.g., renal dialysis was still an experimental procedure, dialysis treatment should be financed at the community level, dialysis treatment should be financed only as part of a broad health

113. Zeckhauser, supra, note 4 , at 447-48. 
insurance bill. The basic issue of the cost of financing dialysis treatment was, however, always understood and sometimes explicitly stated, as in the New York Times editorial comment that "the point is not that victims of renal disease are unworthy of help, but that Government resources have to be allocated to meeting many needs." 114

The proponents of a treatment payment program were only able to achieve their goal as a result of a complex and gradual process. A sequence of federal government actions-involving financing of research and development, demonstration, and capacity-building within HEW, and patient-care financing of eligible veterans by the V.A.- -set the stage for passage of section 2991. The deepening federal role was, in turn, the product of a number of other processes, including the development of an identified group of physicians, the cumulative effect of publicity, and the evolution of the federal role in health in general. In short, although society is reluctant to sacrifice lives for dollars, this reluctance did not swiftly and by its strength alone win federal financing for the victims of end-stage renal disease.

What are the implications of the end-stage renal disease experience for federal policy making relative to other catastrophic diseases? In 1973, a panel of the Institute of Medicine expressed apprehension that the kidney disease provision pointed in the direction of disease-by-disease coverage of catastrophic illness. The panel expressed "unanimous agreement that coverage of discrete categories similar in kind to end-stage renal disease would be an inappropriate course to follow in the foreseeable future for providing expensive care to those who are unable to afford it."115 Though the panel was stating a legitimate concern, there was no disposition to move in the direction they feared at the time of their report and there has been no action in that direction in the four years since the passage of the 1972 social security amendments. Policy attention, instead, has been focused on including medical insurance for other forms of catastrophic disease in either catastrophic health insurance legislation or in an even broader program of national health insurance. The federal role in health would appear to be more controlling of policy determination than the existence of life-saving therapies to which people are denied access because of cost.

On the other hand, were the debate over the form of national health insurance-catastrophic or general-to remain unresolved over an extended time, it is conceivable that pressures could mount in an irresistable manner to do for hemophilia, for instance, what has been done for chronic kidney failure. The kidney experience, however, suggests that the probability of categorical disease-by-disease action being taken would be increased if a number of other factors were present. First, the treatment would have to meet the crite-

114. N.Y. Times, supra note 108.

115. Nat a ACademy of Sciences, supra, note 5, at 6-7. 
rion of being an established therapy, not merely an experimental procedure. Then, the likelihood of patient-care financing would be increased if there had been a prior set of partial government responses to the problem, responses that stopped short of paying treatment costs. Third, the population of identified lives associated with the particular disease would have to grow to a point where the number was politically significant and the plight of such individuals was being continuously dramatized by print and broadcast media. Finally, the probability of government action would be increased if, in addition to the identified patients, there developed an identified set of institutions and group of physicians responsible for providing the particular therapy. If these factors were present, and the larger health insurance debate remained unresolved, disease-by-disease action might be the pathway the country chose to follow.

Finally, an observation about the political process is in order. The policy debate on end-stage renal disease, including the manner of its resolution, suggests that the responsible public officials and professional elites experienced a good deal of difficulty in discussing the question of "who shall live" in a deliberative and public manner. Is the political system capable of openly discussing its policy alternatives and making choices in such circumstances? Or are such choices simply too divisive to be handled well by the polity? If they are too divisive, we may expect vigorous debates on similar cases to be conducted in the inner councils of medical-science and policy making institutions but without extended public discussion. And perhaps we may also expect the resolution of future debates to occur in the almost surreptitious manner witnessed with respect to section 299I. But shielding important policy choices from full and open public discussion robs those decisions of an important measure of legitimacy in the eyes of the public. While financial costs of such decisions may be substantial, the more elusive costs to the polity of choices made without full public participation may be even greater. Perhaps the growing interest in and discussion of the ethical implications of biomedical research, and the meaning and value of life and death, foreshadows a societal capability and willingness to deal with value-of-life questions in a public manner. 